\title{
Puddling Effects on Energy Parameters under Animal Farming for Mechanized Cultivation of Rice
}

\author{
V.M. Victor" ${ }^{* 1}$, A.K. Dave ${ }^{1}$ and A.K.A. Lawrence ${ }^{2}$ \\ ${ }^{1}$ Department of Farm Machinery \& Power Engineering, SV College of Agricultural Engineering \& Technology and Research \\ Station, Indira Gandhi Krishi Vishwavidyalya, Raipur, Chhattisgarh, India \\ ${ }^{2}$ Department of Farm Machinery \& Power Engineering, Vaugh School of Agricultural Engineering, Sam Higginbottom University \\ of Agriculture Technology \& Sciences, Allahabad (UP), India
}

*Corresponding author: vmv_victor@rediffmail.com (ORCID ID: 0000-0002-1428-4951)

Paper No. 867

Received: 14-07-2020

Revised: 28-10-2020

Accepted: $30-11-2020$

\begin{abstract}
Among various agricultural operations, irrigation is one of the highest energy consuming operations followed by tillage operation for seedbed preparation (sowing or transplanting). Studies suggested that for optimal crop yield realization tillage energy use would have to increase. As draught animal (bullocks/ he-buffaloes) uses had been highest (114.8 to $207.3 \mathrm{~h} / \mathrm{ha}$ ) in animal farming and subsequently animal energy use for tillage operations may be decreased by adoption of improved energy efficient implements suiting to local size of draught animals. In the same way manual transplanting of rice consumes higher energy and remains same unless mechanized transplanting of rice is introduced using self-propelled rice transplanters. With this background a study on energy requirement for cultivation of mechanized rice was carried out during 2008 and 2009 with different level of tillage (puddling) under animal farming system. Five different animal drawn puddling equipments (lugged wheel puddler, zigzag puddler, rotary blade puddler, disc harrow cum puddler and indigenous plough) with two level of puddling intensity (two and three passes) were used for development of puddle bed and subsequently rice transplanting was done by using three methods of transplanting viz. transplanting by self-propelled rice transplanter, manually operated rice transplanter and random hand transplanting. Results revealed that input energy for puddling operation depends on the actual field capacity and weight of the puddling equipments. The energy required for puddling operation for each of the equipment increased with varying level of puddling from two passes to three passes. The energy input for puddling operation was highest (19302 $\mathrm{MJ} / \mathrm{ha}$ ) in indigenous plough with three passes and lowest (18270 MJ/ha) in zigzag puddler with two passes. Higher values of energy output-input ratio (7.88) and lower value of specific energy (3.80 MJ/ $\mathrm{kg}$ ) was obtained in rotary blade puddler (three passes). In case of transplanting methods, self-propelled rice transplanter gave significantly highest (7.48) energy output-input ratio and lowest specific energy $(4.15 \mathrm{MJ} / \mathrm{kg}$ ). The puddle bed developed by rotary blade puddler three passes and rice transplanting by self-propelled rice transplanter resulted in higher yield (53.18 q/ha) associated with higher energy output-input ratio (8.63) and lower specific energy $(3.45 \mathrm{MJ} / \mathrm{kg})$ compared to rest of the treatments.
\end{abstract}

\section{Highlights}

(0 Energy input and economics of different puddling and transplanting methods was worked out to find out the energy efficient and cost effective puddling equipment for development of puddle bed suited to the requirements of mechanical transplanters.

(0 Five different types of animal drawn puddling equipments and two types of mechanical transplanters are used in this study.

o Study indicated that rotary tools are energy efficient for puddling operations compared to linear tools.

Keywords: Draught animals, Puddler, Rice, Specific energy, puddling equipments

How to cite this article: Victor, V.M., Dave, A.K. and Lawrence, A.K.A. 2020. Puddling Effects on Energy Parameters under Animal Farming for Mechanized Cultivation of Rice. IJAEB, 13(4): 447-451.

Source of Support: None; Conflict of Interest: None 
Transplanting of rice involves raising of rice seedlings, preparation of puddled fields and transplanting of rice seedlings in the puddled field. Transplanting of rice gives a more uniform crop stand with higher yield than direct seeding of rice (Khan and Gunkel 1988). Traditional practice of puddling was done by ploughing the fields five to six times using animal drawn indigenous plough followed by planking. It consumes lot of energy and increase cost of puddling operation (Sharma 1990). Transplanting of seedling is one of the critical farm operations. Traditional method of transplanting rice seedlings by hand requires a large labour force leading to increase the cost of production (Singh et al. 1997). On the other hand failure to maintain the timeliness of transplanting due to shortage of labour reduces the production (ESCAP 1983). To overcome the problems associated with hand transplanting, mechanical rice transplanters were introduced to reduce the time requirement by mechanizing the transplanting operation.

Many research works has been carried out in different places on tractor, power tiller and animal drawn puddling equipments. Similarly the performance of manually operated rice transplanter, self-propelled rice transplanter and hand transplanting has been evaluated and compared. Lowest specific energy was found in rotary blade puddler and power requirement in first pass was higher than the subsequent two passes (Salokhe et al. 1993b and Dave 1999). Manual transplanting consumed on an average 625 man-h per hectare and a financial gain of 16 per cent in mechanical transplanting by four row manual transplanter over manual hand transplanting (Manian et al. 1987 and Hota 1997). Average cost of mechanical transplanting with eight row self-propelled rice transplanter was found only ₹ 1450 per ha in comparison to ₹ 2550 per ha for manual transplanting (Behera 2000 and Baruah et al. 2001). The energy requirements for mechanical and manual methods of transplanting was found 1074 and $757 \mathrm{MJ} /$ ha, respectively.

Therefore, selection of appropriate energy efficient and cost effective puddling equipment and transplanting method is necessary. Keeping in view the above, a present study has been undertaken to find out suitable soil bed condition prepared by puddling equipment for proper operation of selfpropelled rice transplanter.

\section{MATERIALS AND METHODS}

Field experiments were conducted at research farm of Indira Gandhi Krishi Vishwavidyalaya, Raipur (Chhattisgarh) having silty clay loam soil. To maintain the uniformity in field condition, initially one dry cross ploughing by animal drawn MB plough and flooding the field to saturation was done. To develop puddle bed five types of animal drawn puddlers viz. lugged wheel puddler, zigzag puddler, rotary blade puddler, disc harrow cum puddler and indigenous plough (farmers practice) with two level of intensity - two and three passes were used. These tested puddling treatments were randomized over three transplanting methods viz. manually operated rice transplanter, self-propelled rice transplanter and random hand transplanting. The details of designed treatments are given below:

\begin{tabular}{llll}
\hline Main Treatments & & \\
\hline $\mathrm{T}_{1}:$ & $\begin{array}{l}\text { Lugged wheel puddler } \\
\text { (two pass) }\end{array}$ & $\mathrm{T}_{2}:$ & $\begin{array}{l}\text { Lugged wheel puddler } \\
\text { (three pass) }\end{array}$ \\
$\mathrm{T}_{3}:$ & $\begin{array}{l}\text { Zigzag puddler (two } \\
\text { pass) }\end{array}$ & $\mathrm{T}_{4}:$ & $\begin{array}{l}\text { Zigzag puddler (three } \\
\text { pass) }\end{array}$ \\
$\mathrm{T}_{5}:$ & $\begin{array}{l}\text { Rotary blade puddler } \\
\text { (two pass) }\end{array}$ & $\mathrm{T}_{6}:$ & $\begin{array}{l}\text { Rotary blade puddler } \\
\text { (three pass) }\end{array}$ \\
$\mathrm{T}_{7}:$ & $\begin{array}{l}\text { Disc harrow cum } \\
\text { puddler (two pass) }\end{array}$ & $\mathrm{T}_{8}:$ & $\begin{array}{l}\text { Disc harrow cum } \\
\text { puddler (three pass) }\end{array}$ \\
$\mathrm{T}_{9}:$ & $\begin{array}{l}\text { Indigenous plough } \\
\text { (two pass) }\end{array}$ & $\mathrm{T}_{10}: \begin{array}{l}\text { Indigenous plough } \\
\text { (three pass) }\end{array}$ \\
\hline
\end{tabular}

Sub treatments

$\mathrm{S}_{1}$ : Manually operated rice transplanter

$\mathrm{S}_{2}$ : $\quad$ Self-propelled rice transplanter

$\mathrm{S}_{3}$ : Random hand transplanting

To estimate the energy input in different puddling and transplanting methods standard energy coefficients were used as suggested by Mittal and Dhawan (1988). Use of human, animal, mechanical and other sources of energy were recorded for estimation of energy output-input and specific energy of treatments tested including the production operations and the produce. In the process of estimation of energy input for production of rice the energy inputs for transplanting, nursery preparation, dry tillage, weeding, harvesting and irrigation were taken as average values. The data were analyzed statistically using the technique of analysis of variance. 


\section{RESULTS AND DISCUSSION}

The input energy for puddling operation is depends upon the actual field capacity and weight of the puddling equipments. Operational energy of different animal drawn puddlers for two and three passes has been determined and presented in figure 1 . The energy consumption for puddling operation was found highest in indigenous plough, while the lowest in rotary blade puddler with irrespective of puddling levels. In general, energy requirement for puddling operation was increased with increase in level of puddling from two to three passes. This may be attributed to the fact that three passes of puddling required more time to finish the operation with all the puddling equipments. It was observed that the three passes of indigenous plough $\left(\mathrm{T}_{9}\right)$ required 2.9 times higher energy than three passes of rotary blade puddler $\left(\mathrm{T}_{6}\right)$ for puddling operation. Rotary blade puddler saved 18.93, 38.29 and 42.18 per cent energy requirement than zigzag puddler, disc harrow cum puddler and lugged wheel puddler respectively in three passes of puddling operation.
Energy inputs required for different transplanting methods were estimated and given in Table 1. It revealed that the highest energy (386.16 MJ/ha) was required in hand transplanting $\left(\mathrm{S}_{3}\right)$ which was 1.33 and 1.17 times more than that of transplanting by self-propelled rice transplanter $\left(S_{2}\right)$ and manually operated rice transplanter $\left(\mathrm{S}_{1}\right)$ respectively. However, the minimum energy input (288.62 MJ/ha) was determined for transplanting of rice seedlings under self-propelled rice transplanter $\left(\mathrm{S}_{2}\right)$.

Methods of puddling and transplanting and their effect on different energy parameters, presented in Table 2 depicted that the total energy requirements for the cultivation of rice differed significantly to each other. In puddling treatments, significantly highest input energy (19302.22 MJ/ha) was observed in $\mathrm{T}_{10}$ followed by $\mathrm{T}_{9}$ over rest of the treatments which were statistically similar to each other for all the methods of transplanting. However, minimum energy requirement $(18270.56 \mathrm{MJ} / \mathrm{ha})$ was obtained in $\mathrm{T}_{3}$ which was at par with rest of the treatments except $T_{9}, T_{10}$ and $T_{2}$. Among the transplanting

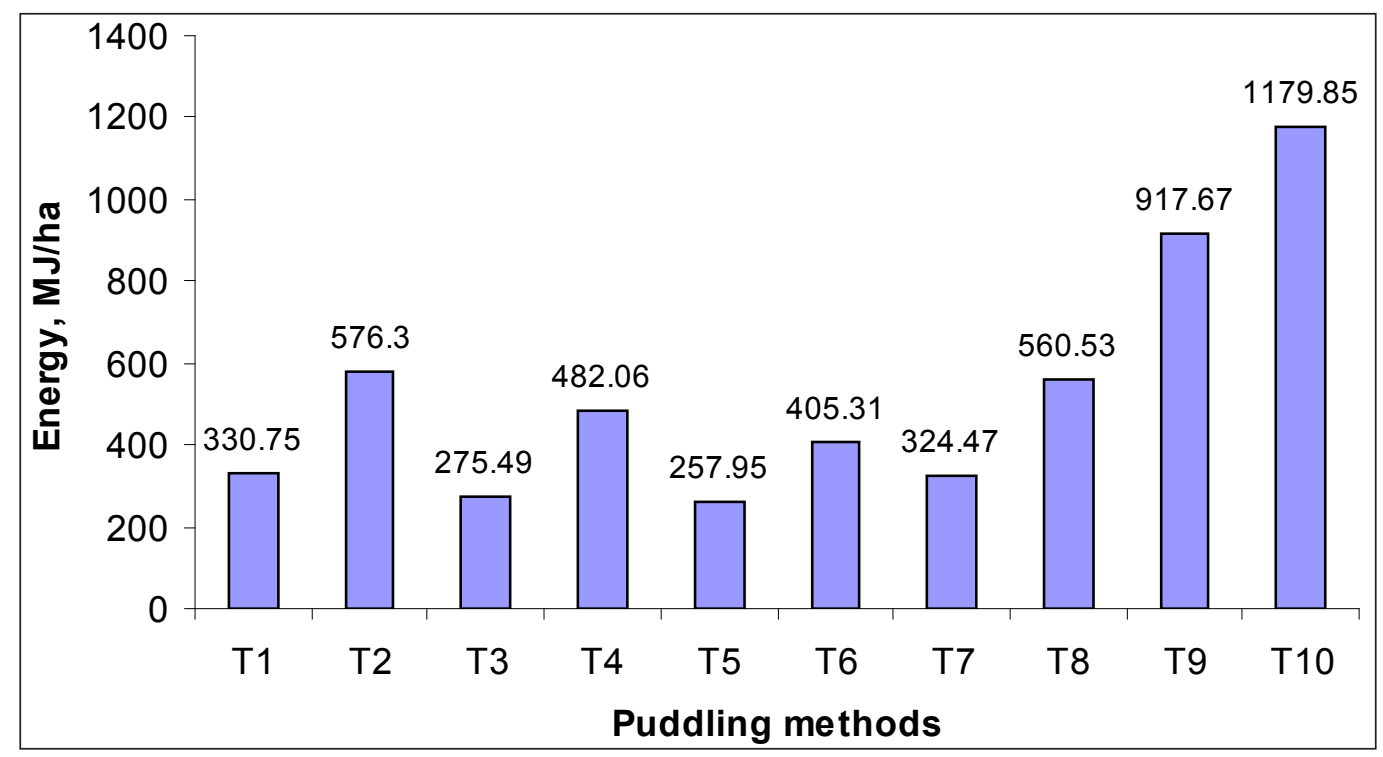

Fig. 1: Operational energy of different pudding methods

Table 1: Operational energy for different methods of transplanting

\begin{tabular}{llllll}
\hline S1. No. & Particular & $\begin{array}{l}\text { Work rate, ha/ } \\
\text { hr }\end{array}$ & $\begin{array}{l}\text { Human-hr/ } \\
\text { ha }\end{array}$ & $\begin{array}{l}\text { Fuel consumed, lit/ } \\
\text { ha }\end{array}$ & $\begin{array}{l}\text { Total operational energy } \\
\text { input, }\end{array}$ \\
\hline 1 & $\begin{array}{l}\text { Single wheel 8 row self-propelled } \\
\text { rice transplanter }\end{array}$ & 0.14 & 49 & 3.42 & 288.62 \\
& Manual 6 row rice transplanter & 0.017 & 168 & - & 329.28 \\
3 & Random hand transplanting & 0.0056 & 240 & - & 386.16 \\
\hline
\end{tabular}


Table 2: Effect of puddling on different energy parameters in mechanized rice cultivation under animal farming

\begin{tabular}{llllll}
\hline Treatments & $\begin{array}{l}\text { Total Input } \\
\text { Energy MJ/ha }\end{array}$ & $\begin{array}{l}\text { Total Output Energy } \\
\text { MJ/ha }\end{array}$ & EOIR & $\begin{array}{l}\text { Specific Energy } \\
\text { MJ/Kg }\end{array}$ & $\begin{array}{l}\text { Grain Yield } \\
\text { q/ha }\end{array}$ \\
\hline Main $\mathrm{T}_{1}$ & 18342.00 & 117079.22 & 6.39 & 4.85 & 38.33 \\
$\mathrm{~T}_{2}$ & 18578.44 & 126470.89 & 6.81 & 4.52 & 41.72 \\
$\mathrm{~T}_{3}$ & 18270.56 & 129701.56 & 7.10 & 4.29 & 42.92 \\
$\mathrm{~T}_{4}$ & 18488.78 & 13849.56 & 7.49 & 4.03 & 46.28 \\
$\mathrm{~T}_{5}$ & 18278.44 & 132069.67 & 7.23 & 4.24 & 43.93 \\
$\mathrm{~T}_{6}$ & 18415.22 & 145005.44 & 7.88 & 3.80 & 48.79 \\
$\mathrm{~T}_{7}$ & 18332.67 & 123780.67 & 6.76 & 4.60 & 40.73 \\
$\mathrm{~T}_{8}$ & 18572.44 & 133954.56 & 7.21 & 4.20 & 44.68 \\
$\mathrm{~T}_{9}$ & 18948.56 & 99438.89 & 5.25 & 5.98 & 32.07 \\
$\mathrm{~T}_{10}$ & 19302.22 & 107658.11 & 5.46 & 0.17 & 34.98 \\
\hline $\mathrm{SEm} \pm$ & 102.21 & 2333.09 & 0.13 & 0.52 & 1.38 \\
$\mathrm{CD}(0.05)$ & 303.69 & 6931.97 & 0.40 & 4.71 & 4.09 \\
Sub $\mathrm{S}_{1}$ & 18483.97 & 122038.83 & 6.57 & 4.15 & 40.36 \\
$\mathrm{~S}_{2}$ & 18443.27 & 137752.23 & 7.48 & 4.98 & 45.50 \\
$\mathrm{~S}_{3}$ & 18731.57 & 116304.10 & 6.22 & 0.09 & 38.47 \\
$\mathrm{SEm} \pm$ & 0.06 & 1189.24 & 0.07 & 0.19 & 0.78 \\
$\mathrm{CD}(0.05)$ & 0.18 & 3399.13 & & & 2.23 \\
\hline
\end{tabular}

methods, treatment $S_{3}$ required maximum energy for rice cultivation followed by $S_{2}$ and $S_{1}$.

The maximum (7.88) energy output-input ratio was observed in $\mathrm{T}_{6}$, which was significantly superior over rest of the puddling treatments. In case of transplanting methods, self-propelled rice transplanter $\left(S_{2}\right)$ gave significantly higher (7.48) energy output-input ratio. Specific energy requirement for per $\mathrm{kg}$ of rice production was found in the range of 3.80 to $5.98 \mathrm{MJ} / \mathrm{kg}$ under puddling and transplanting methods. However, highest (5.98 $\mathrm{MJ} / \mathrm{kg}$ ) and lowest (3.80 MJ/kg) specific energy was required to produce per $\mathrm{kg}$ of rice in $\mathrm{T}_{9}$ and $\mathrm{T}_{6}$ respectively. The minimum $(4.15 \mathrm{MJ} / \mathrm{kg})$ specific energy was obtained in $S_{2}$ among the different transplanting methods. Significant difference was found in energy output-input ratio and specific energy due to puddling and transplanting methods because they also have significant differences in yield This may be attributed to the fact that both the energy parameters depends on grain yield. This is in corroboration with the results of Patel and Das (1992). Interaction effect of puddling and transplanting methods on different energy parameters remained non-significant.

\section{CONCLUSION}

The energy input for puddling operation was highest in indigenous plough and lowest in zigzag puddler with two passes. Higher values of energy output-input ratio and lower value of specific energy $(\mathrm{MJ} / \mathrm{kg}$ ) was obtained for rotary blade puddler (Three passes). In three pass puddling operations compared to two pass the cost of puddling operation ( $₹ / \mathrm{ha}$ ) increased by $42.59,45.45$, 33.33, 42.10 and 22.22 per cent for lugged wheel puddler, zigzag puddler, rotary blade puddler, disc harrow cum puddler and indigenous plough respectively. The cost of transplanting per hectare was ₹ $1490.58,1121.64$ and 2400.00 respectively for manually operated rice transplanter, self-propelled rice transplanter and random hand transplanting.

\section{REFERENCES}

Baruah, D.C., Goswami, N.G. and Saikia, R. 2001. Manual transplanting vs. mechanical transplanting of paddy: A techno economic analysis in Assam. J. Agril. Engg., 38(3): 66-72.

Behra, B.K. 2000. Investigation on puddled soil characteristics in relation to performance of self-propelled rice transplanter. Unpublished Thesis Ph.D., GBPUA \& T, Pantnagar.

Chaudhary, V.P. and Varshney, B.P. 2003. Performance evaluation of self-propelled rice transplanter under different puddled field conditions and sedimentation periods. Agricultural Mechanization in Asia, Africa, and Latin America, 34(2): 23-33.

Dash, R.C., Behra, D. and Pradhan, S.C. 1990. Comparative study on bullock farming and power tiller farming systems for paddy crop. Orissa J. Agril. Res., 3(1): 45-50. 
Dave, A.K.1999. Animal drawn tillage system for rice cultivation under rainfed condition. Agricultural Mechanization in Asia, Africa, and Latin America, 30(3): 28-30.

Dave, A.K., Kumar, P. and Victor, V.M. 2008. Performance of animal drawn plough and puddler in Chhattisgarh conditions. Draught Animal News, No. 46 - Part 1, pp: 42-47.

ESCAP 1983. Testing, Evaluation and Modification of Rice transplanters Technical Series No.13, ESCAP, Regional Network of Agricultural Machinery, Bangkok, Thailand.

Jain, M.L., Sharma, D.N. and Premi, S.C.L. 1991. Field performance evaluation of bullock drawn puddler. Agricultural Mechanization in Asia, Africa, and Latin America, 22(1): 29 -33.

Khan, A.S. and Gunkel, W.W. 1988. Mechanical transplanting of rice in Paikistan. Agricultural Mechanization in Asia, Africa, and Latin America, 19(1): 21-34.

Manian, R., Natrajanmoorthy, K., Chinnanchetty, G. and Kumar, V.J.F. 1987. Evaluation of IRRI transplanter in clay loam soil. Journal Agric. Engg., 24(2): 127-137.

Mittal, J.P. and Dhawan, K.C. 1988. Research manual on energy requirements in agricultural sector, coordinating cell, AICRP on energy requirement in rural sector, PAU, Ludhiana, India.

Mufti, A. I. and Khan, A.S. 1995. Performance evaluation of Yanmar paddy transplanter in Pakistan. Agricultural Mechanization in Asia, Africa, and Latin America, 26(1): 31-36 \& 40

Patel, S.P. and Das, F.C. 1992. Effect of tillage on different energy parameters in rice cultivation. Oryza, 29: 131-135.

Rautaray, S.K. 1993. Performance evaluation of animal drawn puddlers in black soils. Paper presented at the $28^{\text {th }}$ annual convention of ISAE held at CIAE, Bhopal India.
Salokhe, V.M., Miah, H.M. and Hoki, M. 1993b. Effect of blade type on power requirement and puddling quality of rotavator in wet clay soil. Journal of Terramechanics, 30(5): 337-350.

Sharma, R.B. 1990. Evaluation of puddling treatments using animal drawn implements. Agricultural Mechanization in Asia, Africa, and Latin America, 21(1): 32-34.

Sharma, D.N., Jain, M.L. and Premi, S.C.L. 1991. Field performance evaluation of bullock drawn puddler. Agricultural Mechanization in Asia, Africa, and Latin America, 22(1): 29-33.

Shrivastava, A.K. and Datta, R.K. 2005. Comparative performance of some bullock drawn puddlers. J. Agril. Engg., 42(4): 19-24.

Singh, A., Gee-Clough, D. and Singh, G. 1981. Field performance and evaluation of a paddy transplanter. Agricultural Mechanization in Asia, Africa, and Latin America, Spring: 23-30.

Singh, C.P. and Garg, I.K. 1976. Field evaluation of a Japanese paddy tranmsplanter. Journal of Agric. Engg., 13(1): 15-18.

Singh, G.; Sharma, T.R. and Bockhop, C.W. 1985. Field performance evaluation of a manual rice transplanter. Journal of Agric. Engg. Res., 32: 259-268.

Singh, K.N.; Singh, B. and Singh, B. 1973. Performance studies of various puddling equipments. Journal of Agric. Engg., 10: 5-6.

Singh, S., Mittal, J.P. and Verma, S.R. 1997. Energy requirements for production of major crops in India. Agricultural Mechanization in Asia, Africa, and Latin America, 28: 13-17.

Singh, S. and Vatsa, D. K. 2006. Performance evaluation of PAU manual paddy transplanter in hills of Himachal Pradesh. Agril. Engg. Today, 30(3): 19-25. 
